\title{
日本におけるハンセン病の基本治療はどうあるべきか：
}

\section{末梢神経障害防止を最重要課題とした ハンセン病治療の方向性}

\section{畑野研太郎*、松木孝之、牧野正直}

国立療養所邑久光明園

〔受付：1998 年 7 月 7 日〕

\author{
キーワード : ハンセン病、治療、末梢神経障害、再燃の治療
}

バングラデシュにおけるハンセン病治療の前後における末梢神経障害率の変化を検討した。早期診断 を行なっている優秀なプログラムにおいては、治療中に障害率はわずかながら改善されている。しかし、 MBケースの初診時障害率は依然高い。また、MBケースの治療中には、72\%の症例に神経炎を起こす エピソードが見られ、治療後 2 年以上の観察期間にも、15\%の症例がこれらのエピソードを持つことが 観察された。

また、邑久光明園における最近 10年の再燃例の中から、再々燃例の前回再燃時の投薬について検討し た。これらの投薬方法では、おおむね一回投与量が少なく、長期投与がなされる傾向が見られた。 $\mathrm{R} \mathrm{F}$ Pでは投与密度が高く、DDS·B 663 では投与密度が低い傾向があった。

$$
\text { はじめに }
$$

筆者に与えられた課題は、いかに末梢神経障害 を起こさないでハンセン病治療を完了するかとい う議論である。患者にとっては、病気が治るとい う言葉が意味するものは「障害を起こさないで治 療が終わる」ということである。医者側は、普通 は感染症の治療という面を重視しがちであるが、 たとえ感染症としてのハンセン病の治療が完了し ても、障害を残した場合には患者は病気が治った という認識は持ちにくい。逆に障害を起こさない という点を重視する医師の場合には、それぞれの 経験によって治療に様々な変更を加える傾向も見 られる。治療に変更を加えた場合にもその治療が

*Corresponding author :

T 701-4501 岡山県邑久郡邑久町虫明 6253

国立療養所邑久光明園

Tel. 08692-5-0011 Fax. 08692-5-1763

E-mail: pochi@komyo.hosp.go.jp
本当に長期予後も含めて障害率を低下するのに効 果的であるかどうかは、科学的なデーターによる 裏付けが無い場合が多い。

後遺症の発生を低下させる最もよい方法は、言 うまでもなく、早期診断・早期適正治療を実施す ることである。その上で、ハンセン病治療中に、い かにして障害の発生を防止し、あるいは積極的に すでに発生している神経障害を軽快せしめるかを 考えなくてはならない。

しかし現在、日本においてどのような治療を最 も適正なものとするかという議論をすすめように も、新患症例数の少なさ、また、一般に合意され た標準的治療方法が確立されていないために、統 計的な検討をおこなうことが難しい現状である。

現在、筆者等は、厚生省の「国際医療協力研究」 の分担研究である「末梢神経障害の軽減システム の開発」に関わっているので、その調查研究の過 程で得られたデーターをまず紹介し、バングラデ 
シュにおけるハンセン病治療と末梢神経障害発生 の現状について述べる。

ついで、日本のとくに国立療養所においては、 ハンセン病の再燃が特に問題であると考える。経 験的に見ても、再燃を繰り返すごとに末梢神経障 害が進行している現実があるからである。そこで 邑久光明園における最近 10 年の再燃例のうち 再々燃症例を選んで前回の再燃時における投薬に ついて検討したので、その結果を紹介する。

\section{方法と結果}

1. バングラデシュにおけるハンセン病治療と末 梢神経障害

\section{・材料と方法}

主たるデータは、バングラデシュのハンセン病 コントロールに関して、最も先進的な働きをして

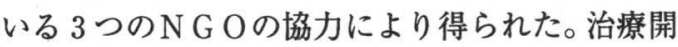
始時および治療終了時における末梢神経障害の程 度を、W H Oの末梢神経障害の程度分類にした がって検討した。なお、ここで行われている治療 は、WHOの勧告に従った期限限定多剂併用療法 が基本であり、それに各プログラムでステロイド 療法等の末梢神経障害防止策が加わえられたもの である。ステロイドの使用法については、それぞ れの間に大きな相違は見られないので、基本的に は同じ投薬方法に従っていると考えても良い。

1. クルナにおける治療終了者数

$\mathrm{PB}=674$ 名 $\mathrm{MB}=173$ 名

(石田裕先生の協力による)

2. ニルファマリーにおける治療終了者数

$\mathrm{PB}=315$ 名 $\mathrm{MB}=471$ 名

(Dr.R.Croft の協力による)

3. チッタゴンにおける、治療終了後経過観察 2 年以上で初診時菌塗抹検査陽性のMB症例数 $\mathrm{MB}=232$ 名

(Dr.A.Mong の協力による)

\section{- 結果}

1.クルナにおける調查結果

$\mathrm{PB}$ ケースの治療前後の障害率の変化は表 1 に
示したとおりである。PBケースでは障害の無い ものが多く、しかも治療による軽快傾向が見られ る。

MBケースの治療前後の障害率の変化は表 2 に 示したとおりである。この表から見られるよう に、全体で見るとハンセン病治療により $\mathrm{PB}$ ケー スの場合と同様に障害率はわずかに減少してい る。ただPBの場合と違い、障害を持たないケー スは 4 割強であり、6 割近い患者がすでに何らか の障害を持っており、治療終了時には治療開始時

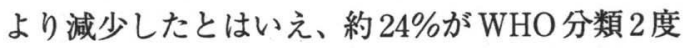
の障害を残している。

\section{2.ニルファマリーにおける調査結果}

PBケースの治療前後の障害率は、表3に示した とおりほとんど変化しない。しかも障害率も非常 に低くて約 $11 \%$ あ゙あったまた、個々のケースで 見ても、増悪が 4 例 $(1.3 \%$ )、改善が 5 例 $(1.6 \%)$ とほほ同数という結果であった。

MB ケースでは、増悪が 37 例 $(7.9 \%)$ 、改善が 19 例（4\%）でわずかに増悪した者の数が改善し た者の数を上回るが、変化の見られない者の割合

\section{表 1 クルナにおけるPBケース}

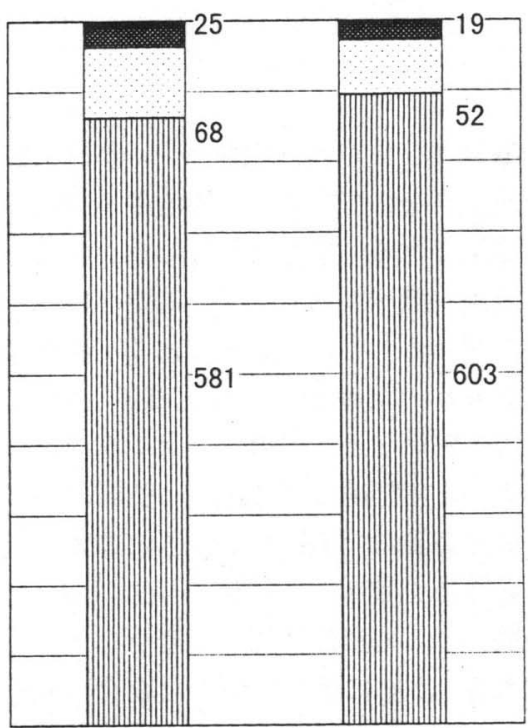

治療開始時

\begin{tabular}{lcc}
\hline $\mathrm{G} 2$ & 25 & 19 \\
\hline $\mathrm{G} 1$ & 68 & 52 \\
\hline 障害無L & 581 & 603 \\
\hline
\end{tabular}


が $88 \%$ と、圧倒的に多いことが観察された。ただ、 クルナでも見られたように、MBケースでは $45 \%$ と多くのものが何らかの末梢神経障害を残すこと が確認された。

\section{3. チッタゴンにおける調査結果}

チッタゴンのプロジェクトからは、最もリスク の高いMBケースの中で、初診時に菌塗抹検査陽 性で、しかも、治療終了後 2 年以上の観察期間を もち得た 232 例について検討を加えた。

これらの治療前後の障害率の変化は表 4 に示し たとおりである。障害率の記載日時が明瞭でない ものは不明とした。これによっても治療後の障害 が無いケースは、治療前より若干増加している。 それでも、何らかの障害を持つものの率は全体の 50\%を越えている。

また、これらの患者の治療中および治療終了後 の末梢神経障害を惹起するエピソードを調査した ところ、表 5 のようになった。神経炎と分類した ものは、Type-1, Type-2 らい反応に含まれない 神経炎である。また、治療終了後観察期間にも、 $15.5 \% の も の に$ 同様のエピソードが観察された。

表 2 クルナにおける MB ケース

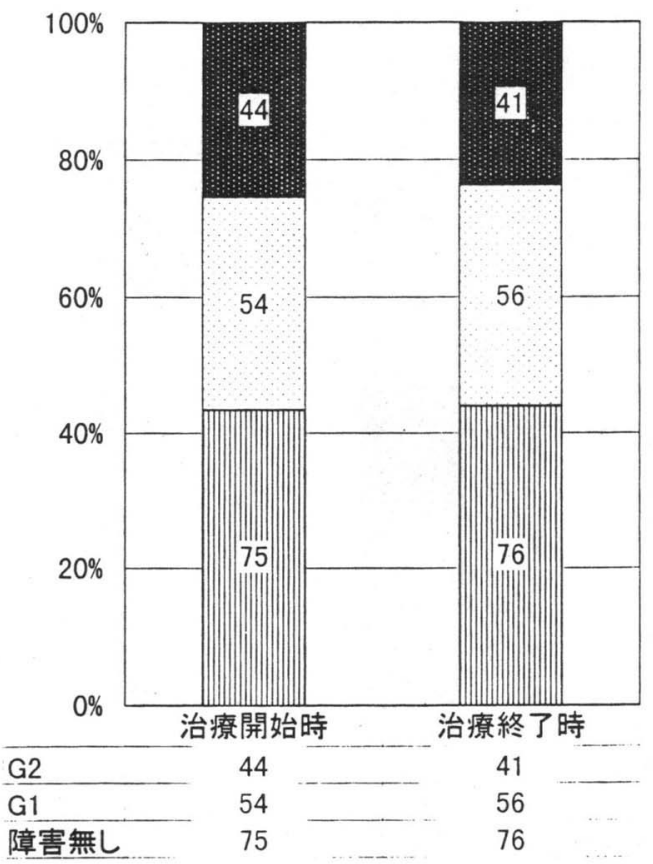

·考察

バングラデシュでの調査開始以前には、末梢神 経障害は治療中に増加すると予想していた。しか し実際は、現在行われているハンセン病化学療法 では、末梢神経障害に対してステロイド療法を積 極的に用いるなどの末梢神経障害防止を念頭にお いた治療が行われるようになってきており、2 年 間の治療期間中には、症状の増悪する者の数と改 善する者の数がほぼ同数を示し、全体としても障 害を持たないものの割合がわずかに増加している ことが判明した。つまり、ハンセン病による末梢 神経障害を持つ者の数の増加に対して、治療中に 見られるエピソード( 1 型反応・ 2 型反応・神経 炎) は、増加要因ではない。

ただし、この結論をバングラデシュ全土に拡大 して適用してよいのかどうかはまだ不明である。 なぜなら、今回の調査結果は、バングラデシュの 中でも最も良いコントロールを行なっていると思 われるNG Oから得られたものだからである。こ の結果の前提条件としては、何よりも早期診断・ 早期適正治療が行われていることが重要であると 思われる。

表 3 ニルファマリーにおける治療前後の末梢神経障害

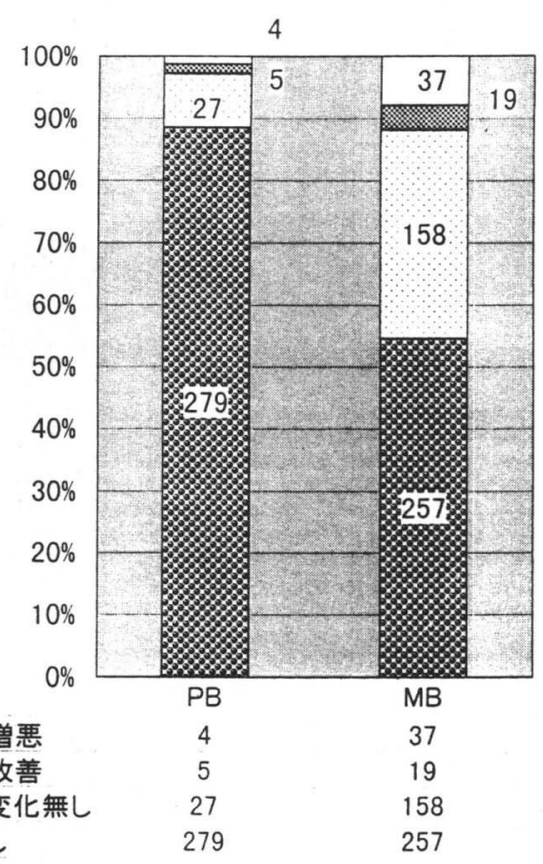


1985年から 1994年までの間は、バングラデシュ のハンセン病新患数は年間約 5000 人程度であっ たが、1998年には1万人を超えるにいたった。こ の事は、ようやくバングラデシュにも不十分なが らコントロールの網がかかりつつあることの証拠 であり、したがって全土的に見ても早期診断可能 な体制に近づきつつあるものと思われ喜ばしい。 しかしすべての地域で、今回入手したと同様の データが得られるかどうかは、はなはだ疑わし い。なぜなら、コントロールにつぎ込まれている 人的·能力的·資金的·組織的な内容において、ま だ驚くほどの地域格差が見られるからである。

また、この三地域においても、MBにおける初診 時障害率はまだまだ高い。これは、以前に比べると 大きく進歩しているとはいえ、相対的には、これら のプログラムですら、今だ新患の発見が遅れてい ることの反映であろう。この治療開始の遅れが、 MB における障害率の高さに反映されている。

また、クルナ、ニルファマリーでの調査を踏ま えて、最もリスクの大きいと思われる、「初診時に 菌塗抹試験陽性例で、治療中および治療後 2 年以 上の経過観察を行ないえた 232 例」を retrospec-

表 4 チッタゴン菌陽性例の治療前後の障害率

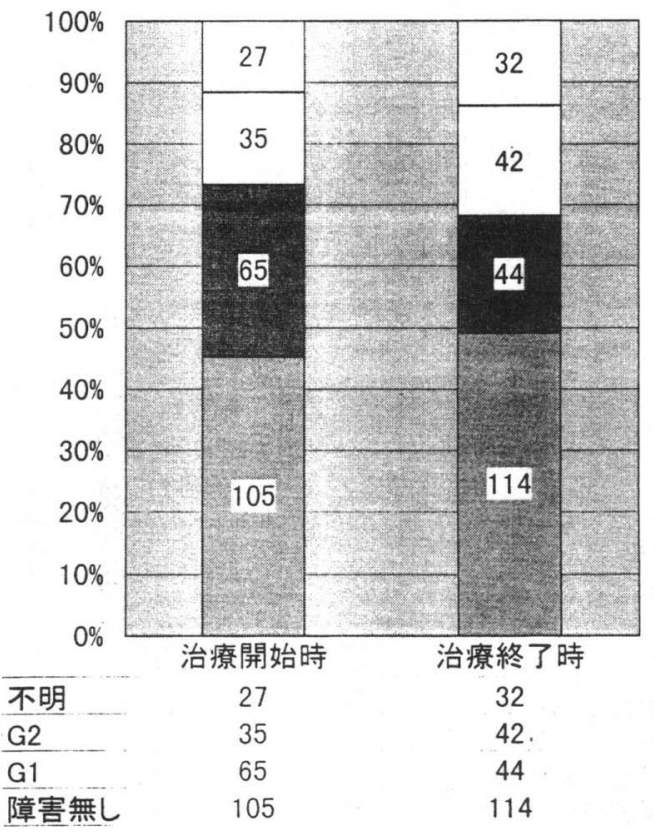

tiveに検討した。

治療期間中に、44例(19\%)に Type-1 反応の、64 例(27.5\%)に Type-2 反応の、そして 59 例 $(25.4 \%) に$ それ以外の神経炎のエピソードが観察され、実に 合計7 $2 \%$ 症例で末梢神経障害を起こす可能性の あるエピソードを持つことが観察された。それに もかかわらず、結果として末梢神経障害の重篤化 が見られないのは、これらのエピソードの早期発 見と適正治療によるものと思われる。

同時に、これらのケースの治療終了後を観察し てみると、Type-1 反応 6 例 $(2.58 \%$ 、 Type- 2 反応 22 例 $(9.48 \%$ 、神経炎 8 例 $(3.4 \%)$ と、神経障害を引 き起こす可能性のあるエピソードが無視すること のできない頻度で起こっていることが判明した。 これらのケースの治療終了時における菌塗抹検査 陽性者は、検査を施行した 165 例中 55 例、実に 33 \%であった。これら治療終了時菌陽性者と治療終 了後の神経炎エピソードの関係について検討して いくことが必要であると思われた。また、治療終 了後に起こる末梢神経障害の進行についても注意 深い検討が必要であると思われる。

\section{表 5 チッタコン菌陽性例の神経障害に関わる} エピソード

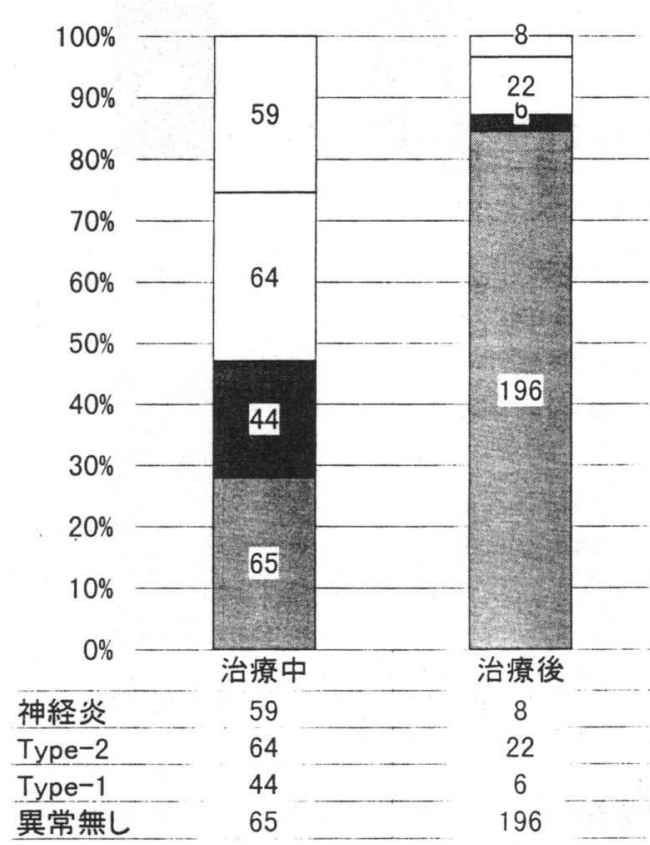




\section{2. 邑久光明園における最近10年の再々燃例の前} 回再燃時における投薬についての検討

\section{- 材料と方法}

邑久光明園において、1989 年から 1998 年の間 に再々燃をきたした 6 症例について、前回再燃時 の投薬について検討した。症例のプロフィールは 表 6 に示す。投薬薬殽、投薬期間、投薬密度、ま た、それぞれの薬剤の併用状況についても検討し た。

投薬薬剤は、R F P、D D S , B 663 , I N $\mathrm{AH}$ ，チバ、プロトゲン、プロミン等が使用され ているが、6 症例で共通して使われており、かつ、 W H O の推奨する投与方法とも比較できる、R F P, D D S, B 663 を選んで比較検討した。

投与期間は、再燃が発見されてから再々燃が発 見されるまでの間での、薬剤が使用されている期 間とした。

投与密度については、毎日投与されている場合 は、1(回) $\div 1$ (日)= 1 とし、例えば週一回投与で あれば、 1 (回) $\div 7$ (日)=0.14としている。

\section{- 結果}

R F P，D D S ，６６3 の投与方法を三次元 の立体グラフとしてあらわしたものが、それぞれ 表 7、8、9 である。氕印はWH O 推奨するM B 2 年、P B 半年の投薬スケジュールにしたがった 場合である。

表 7 に見られるごとく、R F P では、WHOの 投与と比べて、当園の 6 例は一回投与量が $150 \mathrm{mg}$ または $300 \mathrm{mg}$ と低く、投与期間も 4 例は 24 ヶ月よ
りも短期間である。しかし、投与密度は高い。

D D S では、表 8 に示したごとく、投与量は一 例を除いて低い。投与期間はほほ同等のもの 2 症 例以外は長期にわたっている。投与密度は、すべ ての症例でWH Oのものと比べて低い。

B 663 は、表 9 に示したように、WHOのも のと比べて、カプセルの関係から一回投与量は同 等であるが、投与密度は低く、投与期間は長い。

\section{·考察}

今回再々燃例を検討するに先立って、再燃例一 般を検討したが、ほとんどの症例が多剤併用療法 以前の治療を受けているために、現在行なわれて いる治療法と比較することができないばかりでな く、非再燃例と比較しても大きな差を見出すこと ができなかった。

結果で述べたように、今回検討した再々燃例に おいては、WHOの投与方法と比べて、おおむね 一回投与量が少なく、長期投与がなされている傾 向がある。投与頻度については、R F P では高く、 D D SとB 663 では低い。

再燃例が、再々燃を起こす頻度は、WH Oの再 燃頻度に比べいちじるしく高い。これは、さらに 検討されるべき課題である。今回の調査で特に気 になったのは一回投与量の少なさであった。ま た、多剂併用がなされている場合も、R F P·D D S·B 663 が同時に使用されている症例は一例 も無かった。

今回調查した症例は、再燃を起こしたものであ るので、そこには当然、症例の偏りが存在すると 思われる。それゆえ、これらの結果を開発途上国

表 6 再々熱の 6 症例

\begin{tabular}{|c|c|c|c|c|c|c|c|c|}
\hline 症例 & 病型 & 性別 & 誔生年 & 初発 & 再発 & 再々発 & $\begin{array}{c}\text { 3剂以上併用期 } \\
\text { 間の有無 }\end{array}$ & WHO式 \\
\hline 1 & LL & 女 & 1934 & 1946 & 1974 & 1989 & 有 & 無 \\
\hline 2 & LL & 男 & 1925 & 1943 & 1980 & 1998 & 有 & 無 \\
\hline 3 & BL & 女 & 1927 & 1947 & 1976 & 1994 & 無 & 無 \\
\hline 4 & LL & 男 & 1924 & 1940 & 1971 & 1992 & 無 & 無 \\
\hline 5 & LL & 男 & 1937 & 1947 & 1975 & 1995 & 無 & 無 \\
\hline 6 & BL & 女 & 1909 & 1960 & 1978 & 1998 & 有 & 無 \\
\hline
\end{tabular}


で行われているWHOの投薬指針の再燃率と直接 比較することはできないであろう。しかし、再燃 例が特に免疫力の弱い群であると仮定すると、 再々燃を防止するためにもより強力な治療が、障 害の進行を防ぐ注意深い配慮のもとに行われる必 要があったのではなかろうか。

\section{表 7 再々熱例 リファンピシン投与量}

投与密度 vs. 期間 vs. 一回投与

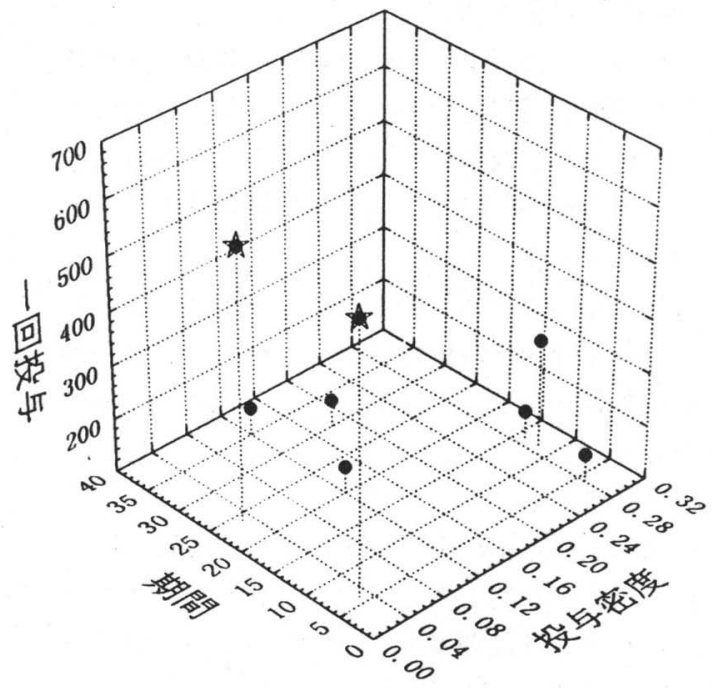

\section{結 論}

以上 1.と 2. の検討から、日本におけるハン セン病化学療法をどうするかという課題に戻っ て、この発題のまとめを行ないたい。
表 8 再々熱例 DDS 投与量

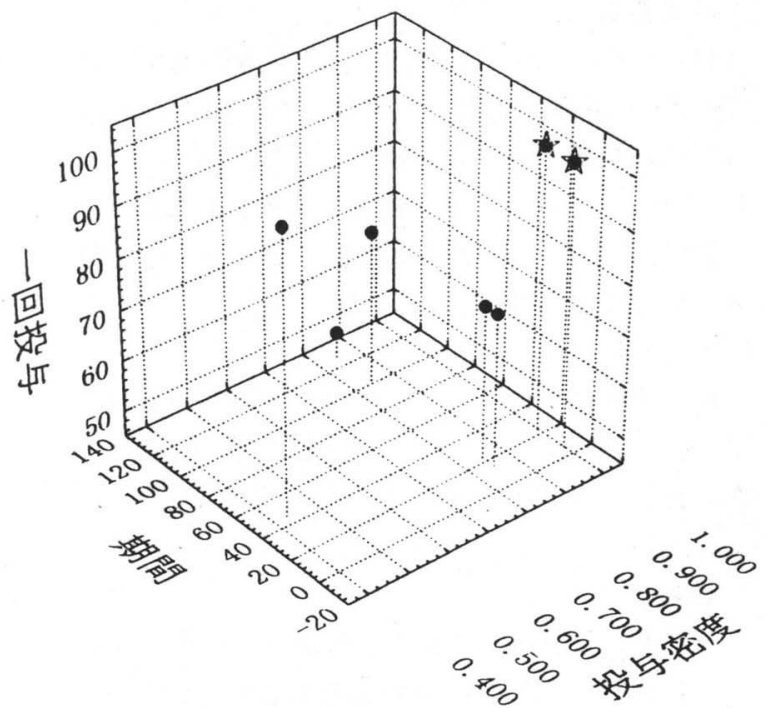

表 9 再々熱例 B 663 投与量

投与密度 vs. 期間 vs. 一回投与

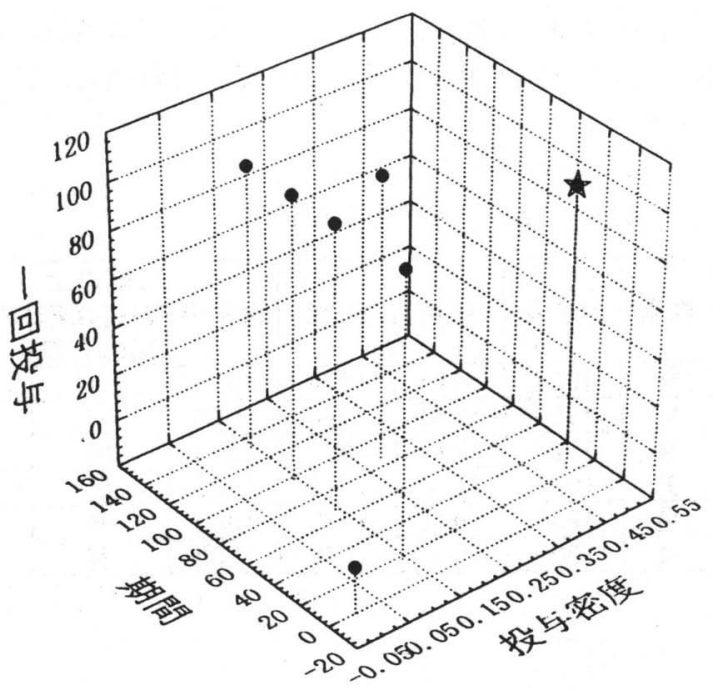


1. ハンセン病治療において末梢神経障害を来さ ないために、最も大切なことは早期診断であ る。現在日本では年間 30 例から多い時には70 例ちかくの帰国マラリアの発症があり、その うちの数例は診断のつかぬうちに不幸の転機 をとると聞くが、新発症の非常に少なくなっ たハンセン病においても、同様に診断の遅れ から高度な末梢神経障害を有する症例が出る ことを恐れる。このような事態を防ぐために も、現在、尾崎元昭先生を中心としてすすめ られているハンセン病患者を全人的に診るこ とのできる専門医のネットワーク作りと、そ の存在を広く宣伝することが重要であろうと 考える。

2. 再燃を起こさない治療を行なうことが、長期 予後をより良いものとする。 それでは、再燃はなぜ起こるのか。

（1）病型の誤認からくる治療選択の誤り。これは 現在開発途上国で問題となりつつある再燃の 原因である。以前に比べて早期発見早期治療 が実行されるようになるにつれて、多菌型で あっても症状の少ない症例が増加しつつあり、
これを少菌型として治療した結果、再燃につ ながるケースが多い。日本の場合は、早期診 断の問題と同様、専門医の少なさが問題とな ると思われ、その点の解決のための方策が必 要であろう。

（2）治療不十分。

(1)で述べたように、WH O の期限限定治療 では、早期診断を前提とするとはいえ、治療 中の末梢神経障害の重篤化はそれほど深刻な 問題ではなさそうである。日本においても、日 常の投薬量という点に関して、WHOの推奨 するものと同等かそれ以上である必要がある と思われる。当然ながらこれらの治療中には、 特にMB症例で末梢神経障害を起こしえるエ ピソードはかなり高頻度に起こるので、十分 の注意が払われなければならない。

問題は、例えばMBケースで 2 年間の治療 が終了した後にも、これらのエピソードが起 こっていることが観察されていることである。 いったいどれくらいの期間治療を続けると充 分な治療がなされたとみなして良いかという 問いは、答えるのに困難な問であるが、今後 とも検討され続けなくてはならないであろう。 


\title{
The trend of leprosy treatment in which the prevention of peripheral nerve damage being as its main theme.
}

\author{
Kentaro Hatano *, Takanobu Matsuki, Masanao Makino, \\ National Sanatorium Oku Komyo-en
}

〔Received 7 Jul 1998〕

Key words: Leprosy, treatment, nerve damage, recurrence of leprosy,

We have examined in leprosy in Bangladesh the change in the rate of peripheral nerve damage before and after the treatment. In the well-organized NGO program where the early diagnose is given, the damage rate improves slightly during the treatment. But among the MB cases, it has been found that the damage rate taken at the time of patient's first check-up still stays high. Furthermore, during the treatment of $\mathrm{MB}$ cases, $72 \%$ cases show the episode of neuritis, and even during two years of observation period after treatment, $15 \%$ cases show the same episode.

Among the recurrent cases of last ten years in Oku-Komyo-en, we have looked into the ways of drugs prescribed for the treatment of previous recurrent term in the double recurrent cases.

In these prescription, the amount of each dosage was relatively a little and the prescription period was rather long. In RFP., prescription frequency was relatively high, and in DDS and CLF, they were low.

We think that the treatment of leprosy in Japan should be based on WHO's regimen. However before making Japanese regimen, it is necessary to discuss more when to finish the treatment.

\footnotetext{
"Corresponding author :

National Sanatorium, Oku-Komyo-en,

6253 Musiake, Oku-cho, Oku-gun, Okayama, 701-4501 Japan

Tel. 08692-5-0011 Fax. 08692-5-1763

E-mail: pochi@komyo.hosp.go.jp
} 